\title{
The Overview of Intermetallic Phases Presented in Nickel Base Superalloys afterPrecipitation Hardening
}

Juraj Belan, Lenka Kuchariková, Eva Tillová, Milan Uhríčik

Faculty of Mechanical Engineering, University of Žilina. Univerzitná 8215/1, 01026 Žilina. Slovakia. E-mail: juraj.belan@fstroj.uniza.sk, lenka.hurtalova@fstroj.uniza.sk, eva.tillova@fstroj.uniza.sk,milan.uhricik@fstroj.uniza.sk.

The nickel base superalloys are progressive group of materials designed especially for application where others materials does not fit with its mechanical properties (such aluminium or copper alloys) or corrosion resistance at high temperature nor heat-temperature properties (such iron or steel). Their unique properties comes from solid solution gamma, where after precipitation hardening a various phases - $\gamma$ (gamma prime), $\gamma^{\prime \prime}$ (gamma double prime), $\delta$ (delta), different types of carbides $\left(M C, M_{23} C_{6}, M_{6} C\right.$, and $\left.M_{7} C_{3}\right)$ with various degree of coherency to matrix are presented. Article gives a brief description of such phases with its affect to mechanical properties.

Keywords: Ni-based superalloys, gamma prime phase, gamma double prime phase, delta phase, metallography evaluation, SEM observation

\section{Acknowledgements}

This work has been supported by Scientific Grant Agency of Ministry of Education of Slovak republic $N^{\circ} 1 / 0533 / 15$, $N^{o} 044 Z ̌ U-4 / 2014$ and project EU ITMS 26110230117.

\section{References}

[1] GLENNY, R., J., E. (1974). High Temperature Materials in Gas Turbines. p. 258. Elsevier, Amsterdam.

[2] DONACHIE, M. J., DONACHIE, S. J. (2002). Superalloys - A technical guide, 2nd ed. ASM International, USA.

[3] DURAND-CHARE, M. (1997). The Microstructure of Superalloys. Gordon \& Breach Science Publishers, Amsterdam.

[4] CHANDLER, H. et al. (2006). Heat Treater's Guide, Practices and Procedures for Nonferrous Alloys, ASM International, USA.

[5] DAVIS, J. R. (2000). ASM Specialty Handbook: Nickel, Cobalt, and Their Alloys, 1st edition, ASM International, Ohio.

[6] RITZERT, F., et al. (1998). The Effect of Alloying on Topologically Close Packed Phase Instability in Advanced Nickel-Based Superalloy Rene N6, NASA TM-1998-206622.

[7] HURTALOVÁ, L., TILLOVÁ, E., CHALUPOVÁ, M., BELAN, J., VAŠKO, A., (2014). Microstructure control of secondary A 231 cast alloy used in automotive industry. In: Manufacturing technology: journal for science, research and production, Vol. 14, No. 3, pp. 326-333.

[8] VAŠKO, A., MARKOVIČOVÁ, L., ZATKALÍKOVÁ, V., TILLOVÁ, E., (2014). Quantitative evaluation of microstructure of graphitic cast irons. In: Manufacturing technology: journal for science, research and production, Vol. 14, No. 3, pp. 478-482.

[9] COPLEY, S. M., KEAR, B. H. (1967). Metallurgical, and Petroleum Engineers. Vol. 239, No. 2, pp. 984 - 989.

[10]COZAR, R., PINEAU A. (1973). Morphology of $\gamma^{\prime}$ and $\gamma^{\prime \prime}$ precipitates and thermal stability of Inconel 718 type alloy. In: Metall. Trans., Vol. 4, pp. 47-59.

[11]VERSNYDER, F. L., SHANK, M. E. (1970). Development of Columnar Grain and Single Crystal High-Temperature Materials through Directional Solidification. In: Materials Science and Engineering, Vol. 6, No. 4, pp. $213-247$.

[12]COLLINS, H. E. (1968). Relative Stability of Carbide and Intermetallic Phases in Nickel-Base Superalloys. In: Superalloys, ASM, Metals Park, OH, 1968, pp. 171 - 198.

[13]CROMPTON, J. S., MARTIN, J. W. (1984). Crack Growth in a Single Crystal Superalloy at Elevated Temperature. In: Metallurgical Transactions A, Vol. 15A, pp. 1711-1719.

[14]BELAN, J., HURTALOVÁ, L., VAŠKO, A., TILLOVÁ, E. (2014). Metallography evaluation of IN 718 after applied heat treatment. In: Manufacturing technology: journal for science, research and production, Vol. 14, No. 3, pp. 262-267.

[15]POLLOCK, M. T., TIN, S. (2006). Nickel-Based Superalloys for Advanced Turbine Engines: Chemistry, Microstructure, and Properties. In: Journal of propulsion and power, Vol. 22, No. 2, pp. 361-374. 